The Journal of Society and Media, April 2021, Vol. 5(1) 58-77

https://journal.unesa.ac.id/index.php/jsm/index

E-ISSN 2580-1341 and P-ISSN 2721-0383

Accredited KEMENRISTEK/BRIN No.148/M/KPT/2020

DOI: 10.26740/jsm.v5n1.p58-77

\title{
The Relationship between Social Status and Students' Consumptive Behaviour
}

\author{
Layli Triana $^{1^{*}}$, Nanang Martono ${ }^{2}$ \\ ${ }^{1,2}$ Faculty of Social and Political Sciences, Universitas Jenderal Soedirman, \\ Purwokerto, Indonesia \\ Email: laylitriana22@gmail.com \\ Email: nanang.martono@unsoed.ac.id
}

\begin{abstract}
Globalization has had some effects the evolution of game forms from traditional to modern. Online games are one of the most common types of modern games. Online games are games that can be accessed by internet-connected and are played on computers, laptops, cellphones, and other devices. Mobile Legends: Bang Bang (MLBB) is the most popular online games in Indonesia. Playing mobile legends online games can have an impact on consumptive behavior among college students. This article explains the relationship between social status and consumptive behavior of Soedirman E-sport Unsoed and explain the relationship between the frequency of playing Mobile Legend Bang-bang (MLBB) with the consumer behavior of Sudirman E-sport students of Jenderal Soedirman University. This study uses a survey method and takes a random sample of 200 members of the Soedirman E-sport Unsoed. The number of samples taken was 67 students. The results showed that first, social status variables were positively related to student consumptive behavior. Both have a correlation value of 0.328 with a significance level of 0.004. The higher the social status, the higher the consumptive behavior of students. Second, the frequency of playing mobile legends online games is positively related to consumptive behavior.
\end{abstract}

Keywords: student, capital, game, consumtive, esport

Paper type: Research paper

*Corresponding author: laylitriana22@gmail.com

Submited: 2020-06-06; Accepted: 2021-04-27; Published: 2021-04-28

Cite this document: Triana, Layli, and Nanang Martono. (2021). The Relationship between Social Status and The Students' Consumptive Behaviour. The Journal of Society and Media, 5(1), 58-77. DOI: 10.26740/jsm.v5n1.p58-77 


\section{INTRODUCTION}

Globalization has had both positive and negative effects in the modern period. Technology has the greatest impact on people's lifestyles. One of the effects of technological advancement is the evolution of game forms from traditional to modern, leading to the coining of the word "modern game." Traditional games suffer as a result of the nature of this new game, which makes them less appealing.

Online games are one of the most common types of modern games. Online games, according to (Utami dan Hodikoh 2020), are games that are played on computers, laptops, cellphones, and other internet-connected devices. Modern culture no longer has to meet face to face in a physical location to play such games thanks to the internet. Now, even if they are in different locations, each person can play together. This is what is referred to as online gaming. Ease of internet access can also be bad if not used properly. According to (Suplig 2017), playing online games has its own story, there are numerous interesting challenges for players to enjoy, and online games often include feelings, such as being personally involved in playing online games. Adams in (Novrialdy 2019), stated that online games will have a positive impact if they are used to fill spare time and entertainment. One of the GO that is popular with many people is Mobile Legends: Bang Bang (MLBB). According to data on the Liputan 6 page (Librianty 2018), MLBB is one of the most popular GO in Indonesia. In 2018, Indonesia had about 50 million monthly active users. Data from (Rizal Fieter dan Ritzky Karina M.R. Brahmana 2018) also shows that the MLBB game has risen to the top of the Google PlayStore's Top Free in Games list. It's no surprise that Indonesia has a large number of MLBB game players.

According to (Valentina dan Sari 2019), MLBB is a type of game that can be played via Android cellphones or computers. According to (Yogatama, Kharisma, dan Fanani 2019), MLBB is a multiplayer online battle arena or MOBA. It is played in the same way as the Playstation, with a virtual joystick on the left directing the speed of the hero and a skill button to attack the enemy. This game is quite interesting, because it can be played as a team. The maximum number of members in a team is five people, so that the MLBB can be played by ten people, including the enemy. This game also raises various hero characters, each player must choose one hero character, and each hero character has a hero skin that is 
various and better than the original version of the skin. Usually, players are interested to buy those skins, and they are willing to spend money in order to obtain the most recent skin from the hero that they want.

According to (Emria Fitri, Lira Erwinda 2018), playing online games actually gives curiosity and gives psychological satisfaction to individuals, making GO more appealing to them. As a result, the more often players purchase skins, the greater the costs incurred so that it can trigger consumptive behaviour. According to (Suminar dan Meiyuntari 2016), consumtive behaviour is the behaviour of consuming goods and services excessively with a high enough intensity to obtain anything better, more costly, and newer, and to demonstrate the social status and wealth in order to obtain satisfaction with something the person already has.

MLBB is frequently competed in various online game competition with quite big prize. To participate in the competition, individuals must practice and play frequently in order to improve their abilities. This must be supported by various facilities that require a lot of money, one of which is the cost of internet access. To minimize internet access costs, individuals can look for free wifi. They are often looking for places that provide wifi, such as: cafes. However, to play GO at a cafe, of course they have to pay for food and drink.

According to data from the viva.co.id page (Saputra R 2018), 47\% of GO players in Indonesia are adolescence aged 21-35 years, then $36 \%$ are children, and $17 \%$ are adults (36-50 years). The data. The data shows that college students are one of the MLBB consumer groups in Indonesia. According to Griffiths a Wood in (Nirwanda dan Ediati 2012), explaining that adolescence is considered to be more frequent and vulnerable in the use of online games.

With the times, college students certainly do not ignore the opportunity to be creative with technology. They also form a community of MLBB fans. One of them is Unsoed students who formed Soedirman E-sport as a form of student activity unit or UKM at Unsoed. Referring to (Bourdieu 2010) statement, playing GO has become a habitus or habit that is influenced by the realm and is supported by the capital owned by college students. Allowance money is one of the capital sources available to them. This is what Bourdieu refers to as economic capital, which is linked to college student expenditure and consumptive behaviour. The amount of allowance is determined by the parents' income level. 
Triana:The Relationship between Social

Status and The Students' Consumptive

Be haviour

According to (Suryani T 2008), purchasing goods or products is influenced by the background of socioeconomic status. A study conducted by (Nurachma dan Arief 2017), shows that the socioeconomic status of parents has a positive effect on students' consumptive behaviour. According to him, parents' socioeconomic status has a $13.91 \%$ impact on on students' consumptive behaviour. This suggests that a student's consumptive behaviour is influenced by his or her parents' socioeconomic status. Since parents' financial capacity to meet their children's needs is influenced by their wages, consumption behaviour is influenced by it. (Elly Anggraeni 2018), research results show that there is a positive and significant influence between the socioeconomic status of parents on the consumptive behaviour of college students of the Faculty of Economics, Semarang State University. The relationship has a partial size of 19.7 percent. According to (Sipunga dan Muhammad 2014), adolescent purchasing behaviour is heavily influenced by socioeconomic status (income). The higher the allowance, the more consumtive behaviour is used. Based on this background, the novelty in this study explains the relationship between social status and the frequency of playing MLBB with consumptive behaviour among Soedirman E-sport Unsoed students, while previous research describes the effect of social status on consumptive behaviour.

\section{METHOD}

This study uses quantitative explanatory method which is intended to test the relationship between hypothesized variables. (Mulyadi 2011) This study employs a survey method by the use of a questionnaire as a primary source of data. (Martono 2014) Sample was obtained through simple random sampling with a sample count taken from a population of 200 college students. An error tolerance of 10\% was determined through Slovin's formula (Sugiyono 2010) with 67 respondents. The hypothesis in this study is that there is a positive correlation between social status and consumptive behaviour in students who participate in Unsoed's Soedirman E-sports club; and a positive correlation between the frequency of GO MLBB playtime with consumptive behaviour in the college students. Data collection methods used in this study include the use of a questionnaire and interviews. Methods of analyzing data used include cross tables and tau kendall correlation. A cross table or contingency table is a table used to 
explain the correlation between two or more variables simply. Aside from cross tables, to determine the value of variable correlation, this study employs the tau kendall correlation test, which is a statistical tool to test associative hypotheses between two variables of ordinal scale data (Yanti dan Akhri 2021).

\section{RESULTS AND DISCUSSION}

Social status is a socio-economic position or level that can be observed by income or occupation in a certain context to differentiate between groups. According to Sugihartono, et al. in (Chotimah, Ani, dan Widodo 2017) the socioeconomic status of parents, include their level of education, occupation, and income. The socioeconomic status of a student's parents is an external factor that can affect the amount of allowance that they may have at their disposal. According to Winke in (Afiati dan Kurniawan 2013), socioeconomic status refers to a state of financial or material security that can be grouped in high, middle, or low socioeconomic statuses.

The indicator variable of social status can be observed in the occupation of a respondent's parents. The following is a table of occupations held by the respondents' parents:

Table 1.

Occupation of College Students' Parents

\begin{tabular}{llcc}
\hline No & Parents' Occupation & Amount & Percent \\
\hline 1 & Freelance & 2 & 3,0 \\
2 & Private Employee & 2 & 3,0 \\
3 & Entrepreneur & 34 & 50,7 \\
4 & Civil Servant & 29 & 43,3 \\
\hline & Total & 67 & 100,0 \\
\hline
\end{tabular}

Source: Primary data processing, 2019

Table 1 shows that a majority of the respondents' parents are entrepreneurs at $50.7 \%$ and a minority of the respondents' parents are freelancers at $3.0 \%$. This indicates that the majority of university students' parents are of a middle-to-upper socioeconomic status.

Data from Table 1 shows that the diversity of occupations held by respondents' parents imply a diversity of income. The following is a table of the income of respondents' parents: 
Triana:The Relationship between Social

Status and The Students' Consumptive

Behaviour 163

Table 2.

Income of Students' Parents

\begin{tabular}{llcc}
\hline No & Income & Amount & Percent \\
\hline 1 & < Rp. 2.000 .000 & 3 & 4,5 \\
2 & Rp.2.000.000- Rp.4.000.000 & 34 & 50,7 \\
3 & $>$ Rp.4.000.000 - Rp.6.000.000 & 17 & 25,4 \\
4 & $>$ Rp.6.000.000 & 13 & 19,4 \\
\hline & Total & 67 & 100,0 \\
\hline
\end{tabular}

Source: Primary data processing, 2019

Regarding the incomes of respondents' parents, according to data listed in Table 2, the $50.7 \%$ majority of respondents' parents generate an income of about Rp.2.000.00-4.000.000, and the minority of respondents' parents generate income of about <Rp. 2.000 .000 (only 4,5\%). Data above indicates that a majority of respondents come from upper-middle class families.

According to (Hanum 2017), income are wages obtained by individuals that are used for purchase or consumption. The income of parents is one source of disposable funds for college students in the form of an allowance. The income of parents affect the amount of allowance a college student may have. The following is a table of respondents' monthly allowance:

Table 3.

University Students' Allowance

\begin{tabular}{|c|c|c|c|}
\hline No & Allowance & Amount & Percent \\
\hline 1 & $<$ Rp. 500.00 & 8 & 12,0 \\
\hline 2 & Rp.500.000 - Rp. 1.000 .000 & 35 & 52,0 \\
\hline 3 & $>$ Rp.1.000.000 - Rp1.500.000 & 10 & 15,0 \\
\hline \multirow[t]{2}{*}{4} & $>$ Rp.1.500.000 & 14 & 21,0 \\
\hline & Total & 67 & 100,0 \\
\hline
\end{tabular}

Data from Table 3 shows that a 52\% majority of respondents have around Rp.500.000-1.000.000 in allowance. This amount of allowance is determined heavily by the amount of income of their parents. The higher the income their parents generate, the higher the amount of allowance that college students are given. According to (Fadilla 2017), the higher income parents are more capable of fulfilling the needs of their children. The following is a table that shows the correlation between parents' income and students' allowance: 
Table 4.

Correlation between Parents' Income and Students' Allowance

\begin{tabular}{|c|c|c|c|c|c|}
\hline \multirow[b]{2}{*}{ Parents' Income } & \multicolumn{4}{|c|}{ Allowance } & \multirow[b]{2}{*}{ Total } \\
\hline & $<\operatorname{Rp} 500 \mathrm{~K}$ & $\begin{array}{c}\text { Rp.500 K - } \\
\text { Rp } 1 \mathrm{M}\end{array}$ & $\begin{array}{l}>\operatorname{Rp} 1 \mathrm{M}- \\
\operatorname{Rp} 1,5 \mathrm{M}\end{array}$ & $>$ Rp1,5 M & \\
\hline \multirow[t]{2}{*}{$<\mathrm{Rp} 2 \mathrm{M}$} & 2 & 1 & 0 & 0 & 3 \\
\hline & $66,7 \%$ & $33,3 \%$ & $0,0 \%$ & $0,0 \%$ & $100,0 \%$ \\
\hline \multirow[t]{2}{*}{$\operatorname{Rp} 2 \mathrm{M}-\mathrm{Rp} 4 \mathrm{M}$} & 5 & 23 & 4 & 2 & 34 \\
\hline & $14, \%$ & $67,6 \%$ & $11,8 \%$ & $5,9 \%$ & $100,0 \%$ \\
\hline \multirow[t]{2}{*}{$>\operatorname{Rp} 4 \mathrm{M}-\operatorname{Rp} 6 \mathrm{M}$} & 0 & 6 & 5 & 6 & 17 \\
\hline & $0,0 \%$ & $35,3 \%$ & $29,4 \%$ & $35,3 \%$ & $100,0 \%$ \\
\hline \multirow[t]{2}{*}{$>\operatorname{Rp} 6 \mathrm{M}$} & 1 & 5 & 1 & 6 & 13 \\
\hline & $7,7 \%$ & $38,5 \%$ & $7,7 \%$ & $46,2 \%$ & $100,0 \%$ \\
\hline \multirow[t]{2}{*}{ Total } & 8 & 35 & 10 & 14 & 67 \\
\hline & $11,9 \%$ & $52,2 \%$ & $14,9 \%$ & $20,9 \%$ & $100,0 \%$ \\
\hline
\end{tabular}

Source: Primary data processing, 2019

Table 4 shows that higher income of parents will result in higher allowances given to students. This shows that the amount of parents' income has an implication on students' allowance. The higher the amount of allowance a college student has can affect the duration of their MLBB playtime. According to (Kolipah dan Devy 2017), high allowances have the potential of enabling excessive consumption of online games. The following is data on the duration of respondents' playtime on the online game, MLBB.

Table 5.

Duration of Respondents' MLBB

\begin{tabular}{clcc}
\hline No & \multicolumn{1}{c}{ Duration } & Amount & Percent \\
\hline 1 & $<2$ & 28 & 41,8 \\
2 & $2-5$ hours & 30 & 44,8 \\
3 & $>5$ hours & 9 & 13,4 \\
\hline & Total & 67 & 100,0 \\
\hline
\end{tabular}

Source: Primary data processing, 2019

Table 5 shows that $44,8 \%$ of respondents spend 2-5 hours a day playing MLBB and 13,4\% of respondents spend more than $>5$ hours playing MLBB. This shows that the majority of university students play MLBB in 2-5 hours durations, with that duration categorized as frequent. Adams and Rollings in (Oktavian, Nurhidayat, dan Nasriati 2018) state that online games are structured to have 
Triana:The Relationship between Social

Status and The Students' Consumptive

B e h a i o u r

different challenges at every level that encourage players to spend a large amount of time to complete every challenge.

A considerably long duration of playing MLBB may be enabled by the amount of allowance obtained by the respondents. The following is a table that implies allowances affect the duration that respondents play MLBB.

Table 6.

Correlation between Allowance and MLBB Playtime

\begin{tabular}{lcccc}
\hline \multirow{2}{*}{ Allowance } & \multicolumn{4}{c}{ Total Duration } \\
\cline { 2 - 5 } & $<\mathbf{2}$ hours & $\mathbf{2 - 5}$ hours & $\mathbf{> 5}$ hours \\
\hline$<$ Rp.500K & 5 & 1 & 2 & 8 \\
& $62,5 \%$ & $12,5 \%$ & $25,0 \%$ & $100,0 \%$ \\
\hline Rp.500K-Rp.1 M & 14 & 16 & 5 & 35 \\
& $40,0 \%$ & $45,7 \%$ & $14,3 \%$ & $100,0 \%$ \\
\hline$>$ Rp.1M-Rp.1,5 M & 3 & 6 & 1 & 10 \\
& $30,0 \%$ & $55,6 \%$ & $10,0 \%$ & $100,0 \%$ \\
\hline$>$ Rp. 1,5 M & 6 & 7 & 1 & 14 \\
& $42,9 \%$ & $50,0 \%$ & $7,1 \%$ & $100,0 \%$ \\
\hline Total & 28 & 30 & 9 & 67 \\
& $41,8 \%$ & $44,8 \%$ & 13,4 & $100,0 \%$ \\
\hline
\end{tabular}

Source: Primary data processing, 2019

Table 6 indicates that not all respondents spend their allowance to play an online game for durations of over $>5$ hours. Playing online games can have an effect on consumptive behaviour; a higher allowance creates a tendency for college students often to play online games. This shows a correlation between the amount of a student's allowance and the duration that they spend playing MLBB.

Consumptive behaviour correlates with the income of parents. The higher the income of their parents, the higher the allowance that college students receive. 
Table 7.

Location of Respondents playing MLBB Games

\begin{tabular}{clcc}
\hline No & $\begin{array}{c}\text { Location of Respondents } \\
\text { Playing MLBB Games }\end{array}$ & Total & Persen \\
\hline 1 & Campus & 3 & 4,5 \\
2 & Home / boarding school & 34 & 50,7 \\
3 & Cafe & 30 & 44,8 \\
\hline & Total & 67 & 100,0 \\
\hline
\end{tabular}

Source : primary data processing, 2019

Table 7 indicates that the majority of respondents olayed MLBB games at home/boarding school as much as $50.7 \%$ and fewer respondents played MLBB games on campus as much as $4.5 \%$. In addition, table 7 shows the location of play in the cafe as much as $44.8 \%$. the result of the interview with the respondents with the initials $\mathrm{AD}$ that he prefers to play outside like in a cafe. The reason is because it is more comfortable,exciting and can play while ordering various foods in the cafe. Another respondent named AJ admitted that when playing MLBB in the cafe he can spend money of Rp 25.000. the nominal is used to buy food and drinks in the cafe. According to AJ, the money is actually enough to buy food twice per day. It means if respondents often play GO MLBB in the cafe then the cost is greater.

In addition, the duration of MLBB play has implications on the amount of the fees required to access the internet. Here are the internet access costs of respondents per month :

Table 8.

The Cost of Student Internet access per month

\begin{tabular}{clcc}
\hline No & Cost of Internet Access & Total & Persen \\
\hline 1 & $<$ Rp 50.000 & 10 & 14,9 \\
2 & Rp50.000-Rp100.000 & 46 & 68,7 \\
3 & $>$ Rp 100.000-Rp 150.000 & 5 & 7,5 \\
4 & $>$ Rp 150.000 & 6 & 9,0 \\
\hline & Total & 67 & 100,0
\end{tabular}

Source: Primary data processed in 2019

Table 8. indicates that most respondents spend Rp. 50.000 - Rp. 100.000 (40.3\%). SF is a respondents who spends internet access costs > Rp. 150.000, he chose an internet package thathas a good network in order to play easily without any internet connection constraints. Meanwhile, Rz calimed to spend Rp $50.000<$ 
Triana:The Relationship between Social

Status and The Students' Consumptive

Beh aviour

to buy internet packages. According to him, the pocket money earned is only enough to buy a cheap internet package.

Table 9.

Relation between duration playing games with Cost of Internet access

\begin{tabular}{|c|c|c|c|c|c|}
\hline \multirow{2}{*}{$\begin{array}{c}\text { Play } \\
\text { Duratio } \\
\mathbf{n}\end{array}$} & \multicolumn{4}{|c|}{ Cost of Internet Access } & \multirow[b]{2}{*}{ Total } \\
\hline & $<\operatorname{Rp} 50.000$ & $\begin{array}{l}\text { Rp.50.000- } \\
\text { Rp100.000 }\end{array}$ & $\begin{array}{l}\text { >Rp100.000 } \\
\text { - Rp150.000 }\end{array}$ & $>\operatorname{Rp} 150.000$ & \\
\hline \multirow[t]{2}{*}{$<2$ hours } & 5 & 16 & 3 & 4 & 28 \\
\hline & $17,9 \%$ & $57,1 \%$ & $10,7 \%$ & $14,3 \%$ & $100,0 \%$ \\
\hline \multirow[t]{2}{*}{$2-5$ hours } & 3 & 24 & 1 & 2 & 30 \\
\hline & $10,0 \%$ & $80,0 \%$ & $3,3 \%$ & $6,7 \%$ & $100,0 \%$ \\
\hline \multirow[t]{2}{*}{$>5$ hours } & 2 & 6 & 1 & 0 & 9 \\
\hline & $22,2 \%$ & $66,7 \%$ & $11,1 \%$ & $0,0 \%$ & $100,0 \%$ \\
\hline \multirow[t]{2}{*}{ Total } & 10 & 46 & 5 & 6 & 67 \\
\hline & $14,9 \%$ & $68,7 \%$ & $7,5 \%$ & $9,0 \%$ & $100,0 \%$ \\
\hline
\end{tabular}

Table 9. indicates that the duration of playing MLBB games is not fully giving an impact on the nominal cost of internet access. Some students use wifi facilities on campus or in the house/kost while playing games, so the respondents do not have to spend additional costs to access the internet. Campus provides free Wifi, while the house/kost requires full payment which is already included in the monthly fee. This is the reason why respondents choose to use wifi when playing MLBB games, so the duration of playing games does not have a big impact on their expenditure because there is another variable, called the location of play. Therefore, the following Table 10 shows the relationship between playing duration with MLBB play location. 
Table 10.

Playing Duration with Play Location

\begin{tabular}{|c|c|c|c|c|}
\hline \multirow{2}{*}{$\begin{array}{c}\text { Play } \\
\text { Duration }\end{array}$} & \multicolumn{3}{|c|}{ Play Location } & \multirow{2}{*}{ Total } \\
\hline & Campus & Home & Cafe & \\
\hline \multirow{2}{*}{$<2 \mathrm{jam}$} & 1 & 10 & 17 & 28 \\
\hline & $3,6 \%$ & $35,7 \%$ & $60,7 \%$ & $100,0 \%$ \\
\hline \multirow[t]{2}{*}{ 2-5jam } & 1 & 20 & 9 & 30 \\
\hline & $3,3 \%$ & $66,7 \%$ & $30,0 \%$ & $100,0 \%$ \\
\hline \multirow[t]{2}{*}{$>5 \mathrm{jam}$} & 1 & 4 & 4 & 9 \\
\hline & $11,1 \%$ & $44,4 \%$ & $44,4 \%$ & $100,0 \%$ \\
\hline \multirow[t]{2}{*}{ Total } & 3 & 34 & 30 & 67 \\
\hline & $4,5 \%$ & $50,7 \%$ & $44,8 \%$ & $100,0 \%$ \\
\hline
\end{tabular}

Source: Primary data processed in 2019

Table 10 indicates 60,7\% respondent play games in Cafe for less than 2 hours ( $<2$ hours). This is because there are restriction time when the respondent choose to playing games in case. There are $66,7 \%$ respondents playing games in their home for 2-5 hours. Wifi access at home can be used without time restrictions, so the respondent can play games as much as they like. $44.4 \%$ of respondents play a game in cade with maximal duration is more than 5 hours ( $>5$ hours) because they often hold a MLBB games tournament. Other than that, the data shows that $11,1 \%$ respondents play MLBB games with a maximal duration of more than 5 hours ( $>5$ hours) on campus. The respondents in this group utilize the available facilities. They use internet access (wifi) on their campus. It means that the duration of playing games is not always showing a correlation with the cost of internet access. Another analysis is the relationship between social status with consumptive behavior variables using a cross table. The following is a cross table of the two variables. 
Triana:The Relationship between Social

Status and The Students' Consumptive

Beh aviour

Table 11.

The relationship between social status with consumptive behavior.

\section{Consumtive Behavior}

\begin{tabular}{lllll}
\cline { 3 - 5 } Social Status & \multicolumn{1}{c}{ Low } & \multicolumn{1}{c}{ Middle } & High & Total \\
\hline Low & 5 & 2 & 2 & 9 \\
$(\mathbf{1 0 0 \% )}$ & 55,6 & 22,2 & 22,2 & 100,0 \\
\hline Middle & 7 & 28 & 7 & 42 \\
$(\mathbf{1 0 0 \%})$ & 16,7 & 66,6 & 16,7 & 100,0 \\
\hline High & 2 & 5 & 9 & 16 \\
$(\mathbf{1 0 0 \%})$ & 12,4 & 31,3 & 56,3 & 100,0 \\
\hline
\end{tabular}

Source : Primary data (2019)

Table 11 indicates cross table analysis of the relationship between low social status and consumptive behavior is $55.6 \%$. Respondents in this group have to use their income according to what is needed. They have to minimize their income so as not to over-behave consumptive. Respondents with middle social status have moderate consumptive behavior at $66.6 \%$. Respondents in this group have moderate consumptive behavior. They use their income according to their needs. Respondents with high social status have high consumptive behavior at $56.3 \%$. This data shows that high status social affects high consumptive behavior. It means that the social economic status of the parents contributes to students' consumptive behavior because parents with high incomes tend to give high income to students.

The result of table 11 shows that there is a positive relationship between social status and behavior consumptive of Soedirman E-Sport students in Jenderal Soedirman University. One of the indicators of social status used in this study is parents' income. Parents income is one of the sources of modal to the students. The amount of parents' income has an effect on the amount of students' income, so the higher the social status, the greater the allowance earned by the students. Then, the higher the allowance earned by the students, the higher the students' consumptive behavior. According to (Putri dan Rahmi 2019), high-income parents will provide enough income to fulfill their son/daughters' needs. While, low income parents will provide less income to fulfill their son/daughters' needs.

Cross table analysis of the variable frequency between playing MLBB with a consumptive behavior variable is presented in table 12 . 
Table 12.

The relationship frequency between playing online games MLBB with consumptive behavior. The following is the result of calculating the correlation value of Tau Kendall using SPSS :

\begin{tabular}{|c|c|c|c|c|}
\hline \multirow{2}{*}{$\begin{array}{l}\text { Frequency of } \\
\text { playing games }\end{array}$} & \multicolumn{3}{|c|}{ Consumptive Behavior } & \multirow[b]{2}{*}{ Tota } \\
\hline & Low & Middle & High & \\
\hline Low & 9 & 12 & 1 & 22 \\
\hline$(100 \%)$ & 40,9 & 54,5 & 4,5 & 100,0 \\
\hline Middle & 4 & 20 & 9 & 33 \\
\hline$(100 \%)$ & 12,1 & 60,6 & 27,3 & 100,0 \\
\hline High & 1 & 3 & 8 & 12 \\
\hline$(100 \%)$ & 8,3 & 25,0 & 66,7 & 100,0 \\
\hline
\end{tabular}

Table 12 indicates that the respondents with the playing frequency group rarely have low consumptive behavior of $41,0 \%$. Respondents in this group have low expenses when the respondents playing MLBB games. Respondent with the playing frequency group have middle consumptive behavior of $60.6 \%$. Respondent in this group can control their income well so as not to buying something that they don't needs. Respondents with the playing frequency group very often have high consumptive behavior of $66.7 \%$. Respondents in this group assume that skin hero as a necessity. Most of them are pro players who can often participate in MLBB tournaments.

Table 12 shows that there is a positive relationship between frequency of playing mobile legend with consumptive behavior of Soedirman E-sport Unsoed students. Therefore, the more students playing MLBB games, the higher thei consumptive behavior.

Correlation test to explain social status relationship (X1), frequency of playing mobile legends online games (X2) with consumptive behavior (Y) using tau kendall $(\tau)$. This following is the result of calculating the tau kendall correlation value using SPSS : 
Triana:The Relationship between Social

Status and The Students' Consumptive

Be haviour

Table 13.

Result of Tau Kendall correlation analysis on Social Status Relationship (X1), playing frequency MLBB (X2) with consumptive behavior (Y)

\begin{tabular}{|c|c|c|c|c|c|}
\hline & & & $\begin{array}{l}\text { Social } \\
\text { Status }\end{array}$ & $\begin{array}{l}\text { Frequency } \\
\text { of Playing } \\
\text { Games }\end{array}$ & $\begin{array}{l}\text { Behavior } \\
\text { Consum } \\
\text { ptive }\end{array}$ \\
\hline \multirow[t]{9}{*}{$\begin{array}{l}\text { Kendall's } \\
\text { tau_b }\end{array}$} & \multirow[t]{3}{*}{$\begin{array}{l}\text { Social } \\
\text { Status }\end{array}$} & $\begin{array}{l}\text { Correlation } \\
\text { Coefficient }\end{array}$ & 1,000 & , 159 &, $328^{* *}$ \\
\hline & & Sig. (2-tailed) & & , 159 & ,004 \\
\hline & & $\mathrm{N}$ & 67 & 67 & 67 \\
\hline & \multirow{3}{*}{$\begin{array}{l}\text { Frequency } \\
\text { of Playing } \\
\text { Games }\end{array}$} & $\begin{array}{l}\text { Correlation } \\
\text { Coefficient }\end{array}$ & ,159 & 1,000 &, $453^{* *}$ \\
\hline & & Sig. (2-tailed) & , 159 & . &, 000 \\
\hline & & $\mathrm{N}$ & 67 & 67 & 67 \\
\hline & \multirow{3}{*}{$\begin{array}{l}\text { Behavior } \\
\text { Consumpt } \\
\text { ive }\end{array}$} & $\begin{array}{l}\text { Correlation } \\
\text { Coefficient }\end{array}$ &, $328^{* *}$ &, $453^{* *}$ & 1,000 \\
\hline & & Sig. (2-tailed) & ,004 & ,000 & . \\
\hline & & $\mathrm{N}$ & 67 & 67 & 67 \\
\hline
\end{tabular}

**. Correlation is significant at the 0.01 level (2-tailed).

Source: Primary data presented in 2019

The correlation result of social status variable on consumptive behavior is $0.328 * *$. The correlation value is in the sufficient category, so it can be conclude that the relationship between social status and consumptive behavior is sufficient. Previous data shows that despites the respondents have high enough income (Rp 500.00 s.d 1.000.000), but they don't necessarily playing MLBB at a high cost. Data in table 9 shows that most of the respondents choose playing games in their home or campus, so they do not have to spend the high cost of internet access. Respondent prefer to utilize the wifi facilities in their home or campus.

The result of this study are reinforced by (Astuti 2016), entitled The Influence of Parents' Socioeconomic Status, Economic Literacy and Life Style on Consumption Behavior in the Department of Economic Education, IKIP PGRI Bojonegoro, which states that the regression coefficient value is (b) 0.814 . At the $5 \%$ significance level with a count of 8,299 with a significance value of 0,000 because the regression coefficient has a positive value and a probability significance value of $0,000<0.05$. From this study, it can be concluded that the variable of parents' socioeconomic status has a positive effect on consumption behavior. 
The significance test of the relationship between social status, the frequency of playing online mobile legends games with consumptive behaviour is measured with $\mathrm{p}$ value $\leq 0,05$. So, the relationship between variables is significant. Based on table 13, it shows that the relationship between social status and consumptive behaviour has a value of 0,004 . The value is less than 0,05 . It means that the relationship is significant. It also means that the result of this study can be generalized at the population level with an error rate of $0.4 \%$.

The result of variable correlation of playing games online mobile legends with consumptive behaviour is $0,453 * *$. The values are included in a sufficient category. Based on table 6 , respondents do not always spend their income on playing online games. Based on data in table 8 shows that most of the respondents spent their internet access cost in the range of Rp 50.000 - Rp 100.00. That means the duration of playing MLB games does not fully affect the cost of internet access. The significance test of the relationship between frequency of playing games and consumptive behaviour measured by the formula values $\leq 0.05$, so the variable relationship is significant. Based on table 14, it shows that the relationship between the frequency of playing mobile legends and consumptive behaviour has a value of 0,000 . The value is less than 0.05 which means the relationship is significant. It also means the result of this study can be generalized in population level with error rate of $0 \%$.

This value is included in the sufficient category. As is already explained in the previous part, the respondents prefer to utilize wifi facilities on campus or in the home/kost when they are playing MLBB games. So, the respondents don't have to spend their additional cost to access the internet. Wifi that is already provided by the campus is free, while wifi provided by the home/kost have to pay the full payment which is already included in the monthly fee. These are the reasons why respondents choose to utilize wifi when they are playing MLBB games.

The reinforcement in this study is supported by (Bourdieu 2010), which states that GO playing behavior is a result of the relationship between students themselves and the structure occupied by students in various domains. Consumptive behavior is a habitus or habit that is influenced by certain domains and is supported by the existence of capital owned by students. This means that students' online game play behavior is caused by a habit or habitus. According to (Ritzer, G., \& Goodman 2008), habitus is mental or cognitive that is played by individuals in 
dealing with their social life. individuals will be equipped with schemes/patterns that exist in social life which are internalized within the individual to feel, understand, realize and assess the social world. Through this pattern individuals produce their actions and behaviour. Students play online games due to habit that has been internalized since childhood. Since childhood, students have been introduced to digital games such as the Playstation by their parents and their loved ones. The internalized patterns/schemes enter within the individual. They will follow the habit that playing is like playing the playstation.play without having to leave the house which can endanger individuals if playing outside the house. This is because of their parents' habitation since childhood, so they play it repeatedly even today. With the advent of online games, it has increased their interest in playing. Online games are just a substitute for the playstation they play, because online games are easier to play. This has formed a habitus/habit.

The habits that the students have owned will happen continuously. This is influenced by the realm. According to (Bourdieu 2010), the realm is the place for competition and struggle. Individual that involve in various spheres, be it politics, art, or intellectuals, of course have to understand and master the rules that exist in that scope. Because every environment that individuals live in has its own rules. The realm of student is the Soedirman E-sport community. The existence of Sudirman E-sport is one of the drivers of consumptive behaviour. This is because their environment, which both play online games, encourages them to play frequently. This is supported by the existence of capital owned by students. Capital/ capital according to Bourdieu consists of economic, social, and cultural symbols. One source of capital for students is income that is obtained from their parents. Bourdie calls this economic capital. The amount of income correlates with students expenditure and consumptive behavior. The higher the allowance, the more often they play mobile legends online games. That means playing mobile online games can affect consumptive behavior.

The games "instant" and "practical" are the main attraction for many groups, especially done then become "binders" for individuals who have the same hobby, even if they form a community. Modern individuals make online gaming a hobby, some people even make GO work, so they can earn a lot of income by playing GO. There are many GO competitions that many GO addicts participate in. 
GO competitions that are held in many places show that the GO trend is also being used by capitalists to make a profit. GO is an intermediary for capitalists to take advantage of its players as objects.

The result of this study indicates that some respondents are "willing" to put themselves in front of their respective devices for hours, some even more than five hours a day (table 10). They become capitalist objects that provide internet access (mobile operators) as well as GO internet access (mobile operators) as well as GO developers because MLBB also offers additional paid features. Socialization of GO users has been transferred to virtual socialization through GO, they are alienated from the real world. This is a phenomenon of modern society which prioritizes interaction in cyberspace in all its forms.

\section{CONCLUSION}

The result of this study indicates that there is a positive relationship between social status and consumptive behavior with a correlation value of 0.328 . The significance test of the relationship between social status and consumptive behavior has a value of 0.004 . The higher the social status, the greater the allowance for students. The greater the allowance given by parents, the higher the student's consumptive behavior. Second, there is a positive relationship between the frequency of playing mobile legends online games with consumptive behavior with a correlation value of 0.453 . The significance test of the relationship between the frequency of playing mobile legends online games and consumptive behaviour has a value of 0.000. playing mobile legends online games can have an impact on consumptive behavior. The more often students play MLBB, the higher the students' consumptive behavior.

\section{REFERENCES}

Afiati, Bintana, dan Yonisa Kurniawan. 2013. "Pengaruh Status Sosial Ekonomi Orang Tua dan Konsumsi Siswa Kelas Xi Ips Man Sidoarjo.” Jurnal pendidikan ekonomi UNESA 1-17.

Astuti, Rika Pristian Fitri. 2016. "Pengaruh Status Sosial Ekonomi dan Life Style Terhadap Perilaku Konsumsi Mahasiswa Jurusan Pendidikan Ekonomi IKIP PGRI Bojonegoro.” Jurnal Edutama 3, No. 2:49-58. 
Bourdieu, Pierre. 2010. Arena Produksi Kultural: Sebuah Kajian Sosiologi Budaya. Yogyakarta: Kreasi Wacana.

Chotimah, Lilis Nur, Hety Mustika Ani, dan Joko Widodo. 2017. "Pengaruh Status Sosial Ekonomi Orang Tua Terhadap Prestasi Belajar Siswa (Studi Kasus Siswa Kelas VIII SMP Negeri 1 Jember Tahun Ajaran 2016/2017)." JURNAL PENDIDIKAN EKONOMI: Jurnal Ilmiah Ilmu Pendidikan, Ilmu Ekonomi dan Ilmu Sosial 11(1):75.

Elly Anggraeni, Khasan Setiaji. 2018. "Pengaruh Media Sosial Dan Status Sosial Ekonomi Orang Tua Terhadap Perilaku Konsumtif Mahasiswa." Economic Education Analysis Journal 7(1):172-80.

Emria Fitri, Lira Erwinda, Ifdil Ifdil. 2018. “Konsep Adiksi Game Online dan Dampaknya terhadap Masalah Mental Emosional Remaja Serta Peran Bimbingan Dan Konseling." Jurnal Konseling dan Pendidikan 4(3):21119.

Fadilla. 2017. "Pengaruh Penghasilan Orang Tua dan Uang Saku Terhadap Prestasi Mahasiswa (STEBIS IGM).” Jurnal Keuangan dan Bisnis 15(1):28-53.

Hanum, Nurlaila. 2017. "Analisis Pengaruh Pendapatan Terhadap Perilaku Konsumsi Mahasiswa Universitas Samudra di Kota Langsa." Jurnal Samudra Ekonomika 1(2):107-16.

Kolipah, Siti, dan Shrimarti Roekmini Devy. 2017. "Pengaruh Ketahanan Keluarga Terhadap Kegemaran Bermain Game Online Pada Siswa Sd Di Kelurahan Mulyorejo.” Jurnal PROMKES 4(1):104.

Librianty, Andina. 2018. "Indonesia Penyumbang Pengguna Aktif Terbesar untuk Mobile Legends.” Www.Liputan6.Com.

Martono, Nanang. 2014. Metode Penelitian Kuantitatif: Analisis Isi dan Analisis Data Sekunder. Jakarta: PT Raja Grafindo Persada.

Mulyadi, Mohammad. 2011. "Penelitian Kuantitatif dan Kualitatif Serta Pemikiran Dasar Menggabungkannya [Quantitative and Qualitative Research and Basic Rationale to Combine Them]." Jurnal Studi Komunikasi dan Media 15(1):128.

Nirwanda, Cesaria Septa, dan Annastasia Ediati. 2012. "Adiksi Game Online dan Keterampilan Penyesuaian Sosial.” Jurnal Empati 5(1):19-23.

Novrialdy, Eryzal. 2019. "Kecanduan Game Online pada Remaja: Dampak dan Pencegahannya.” Buletin Psikologi 27(2):148. 
Nurachma, Aulia, dan Sandy Arief. 2017. "Pengaruh Status Sosial Ekonomi Orang Tua, Kelompok Teman Sebaya Dan Financial Literacy Terhadap Perilaku Konsumtif Pada Siswa Kelas Xi Ips Sma Kesatrian 1 Semarang Tahun Ajaran 2015/2016.” Economic Education Analysis Journal 6(2):489-500.

Oktavian, Nindar, Saiful Nurhidayat, dan Ririn Nasriati. 2018. "Pengaruh Durasi Bermain Terhadap Adiksi Game Online Pada Remaja Di Warung Internet XGC Kecamatan Dolopo Kabupaten Madiun.” Health Sciences Journal 2(2):72.

Putri, Hermai Nisa, dan Elvi Rahmi. 2019. "Pengaruh Pendapatan Orang Tua terhadap Perilaku Keuangan Mahasiswa Pendidikan Ekonomi FE UNP.” Jurnal Ecogen 2(3):315.

Ritzer, G., \& Goodman, D. J. 2008. Teori Sosiologi: Dari Teori Sosiologi Klasik Sampai Perkembangan Mutakhir Teori Sosial Postmodern. Yogyakarta: Kreasi Wacana.

Rizal Fieter dan Ritzky Karina M.R. Brahmana. 2018. "Pengaruh Online Experience Terhadap Loyalty Melalui Satisfaction Pemain Mobile Legends." Agora 6(2):287183.

Saputra R. 2018. "Fakta dan Data Game Online.” www.viva.co.id.

Sipunga, Puspita Nilawati, dan Amri Hana Muhammad. 2014. "Kecenderungan Perilaku Konsumtif Remaja Ditinjau dari Pendapatan Orang Tua Pada Siswa-Siswi SMA Kesatrian 2 Semarang.” 3(1d):62-68.

Sugiyono. 2010. Metode Penelitian Kuantitatif, Kualitatif dan $R \& D$. Bandung: Alfabeta.

Suminar, Eva, dan Tatik Meiyuntari. 2016. "Konsep Diri, Konformitas dan Perilaku Konsumtif pada Remaja.” Persona:Jurnal Psikologi Indonesia 4(02).

Suplig, Maurice. 2017. "Pengaruh Kecanduan Game Online Siswa SMA Kelas X Terhadap Kecerdasan Sosial Sekolah Kristen Swasta Di Makassar.” Jurnal Jaffray 15(2):24.

Suryani T. 2008. Perilaku Konsumen: Implikasi Pada Strategi Pemasaran. Yogyakarta: Graham Ilmu.

Utami, Tantri Widyarti, dan Atik Hodikoh. 2020. "Kecanduan Game Online Berhubungan Dengan Penyesuaian Sosial Pada Remaja." Jurnal Keperawatan 12(1):17-22.

Valentina, Elvi, dan Wulan Purnama Sari. 2019. "Studi Komunikasi Verbal dan Non Verbal Game Mobile Legends: Bang Bang.” Koneksi 2(2):300. 
Triana:The Relationship between Social

Status and The Students' Consumptive

Be h a viour

Yanti, Cici Apriza, dan Ilham Julian Akhri. 2021. "Perbedaan uji korelasi pearson, spearman dan kendall tau dalam menganalisis kejadian diare." 6(1):51-58.

Yogatama, I. Ketut Sidharta, Agi Putra Kharisma, dan Lutfi Fanani. 2019. “Analisis Faktor-faktor yang Memengaruhi Minat Pemain dalam Permainan MOBA (Studi Kasus: Mobile Legends: Bang-Bang!)." Jurnal Pengembangan Teknologi Informasi dan Ilmu Komputer 3(3):2558-66. 